\title{
EFFECTS ON THE REGISTRATION AND LICENSING OF MICROENTERPRISES IN AN INFORMAL ECONOMY: FURTHER EVIDENCE FROM THE OTA AREA, NIGERIA
}

\author{
EBENEZER BOWALE, ADEDAYO ODUKOYA, PHILLIP ALEGE \& TOLU AKIODE \\ Department of Economics and Development Studies, Covenant University, Nigeria
}

\begin{abstract}
This study examined the effects of business formality on microenterprises in an informal economy, with particular reference to the Ota area in Ogun State, Nigeria. This study area reflects the typical Nigerian business environment with all the characteristics of an informal economy. Data were collected using questionnaires from a sample of 200 microenterprises. The owners of 161 microenterprises responded ( 81 per cent response rate). The sampling frame for the survey consisted of microenterprises that employ no more than 10 workers. Five lines of businesses were identified for the survey. These included light manufacturing, trading, agro-allied, vocation and professional services. These businesses provided a good representation of the self-employed and small employers in the study area. The questionnaire comprised three sections: a socio-demographic profile in section A, the businesses characteristics of the microbusinesses in Section B, and the underlying factors that influence the capacity of small and medium-sized enterprises to generate income in section $\mathrm{C}$. The data collected were analysed using descriptive statistics. A probit model was used to estimate the identified variables. The results showed that most (69\%) of the microenterprises surveyed were owned by males. The main business in the area was trading. The results also revealed that most (65\%) of the enterprises have been in operation for more than five years. It was also discovered that the majority of the business owners had not registered their businesses with government agencies; instead, most of them had registered with local organizations. Few of them $(35 \%)$ had licensed their businesses. Furthermore, the results showed that gender (coef. $=0.394, p<0.01$ ) and business focus (coef. $=0.297, p<0.05$ ) were significant factors determining the income generation potential of microenterprises. However, business type, business registration, licensing, age of business, educational level, and age of owners were not significant in determining the income generation of the firms. The study concluded that business formality (registration and licensing) has no significant effect on the income-generation potential of microenterprises in the Ota area, Nigeria.
\end{abstract}

Keywords: microenterprises, formality, income, Ota area, Nigeria.

\section{INTRODUCTION}

The formalization of micro, small and medium-sized enterprises (MSMEs) has been an important issue in development globally. The number of informal businesses is currently on the increase due to the effects of globalization. Informal businesses are also found in the formal sector as goods and services now find their way into micro and small-scale informal units in many economies. Furthermore, a great proportion of the labour force in the informal economy is now on the increase (Chen [1]). Literature is replete with the determinants of factors influencing enterprise profitability and the nexus between a firm's outcome and business formalisation. Some studies showed that formalisation has a lot of advantages. There is evidence to show that it enhances productivity as well as employment and income levels (Fajnzylber et al. [2]). However, some scholars believe that there are some other factors such as education, capital and political stability that could affect business growth. Some are of the opinion that the reduction of regulations could enhance business formalization and, hence, firm growth. Some hold the belief that the size of a firm can encourage formalization. Some also argue that the relationship between formalization 
and the growth of small and medium-sized enterprises (SMEs) is reciprocal. Using data from the World Bank's sponsored survey of micro and small enterprises, Bruhn and McKenzie [3] analysed the effect of formalisation in Bolivia and found that formalisation reduces the profit of microenterprises and large enterprises. In Nigeria, there is no consensus on the impact of formalisation on the income of microenterprises, hence this study.

\section{LITERATURE REVIEW}

The informal economy has been traditionally associated with developing countries (De Soto [4]). There are different schools of thought on the issue of informal economy. Some view the informal sector as distinct and having nothing to do with the formal sector, whereas the 'structuralists' believe that informal and formal economies are linked. Others look at the issue from a legal point of view by focusing on the problem of entry of informal to formal economy. The 'voluntarists' believe that informal firms dodge tax and do not want to formalize their businesses. Some believe that those who have the money to engage in a formal economy can decide to operate in an informal economy (Paul and Wallace [5], Portes and Sassen-Koob [6]). A lot of theories have been proposed for the reasons for the informal economy. Some believe that the informal economy provides space for those with socioeconomic status to carry out their activities (Ferman and Hoyman [7]). Some theories argue that people turn to the informal economy for survival when they lose their jobs in the formal economy.

There are different descriptions of the informal sector. Some scholars have referred to it as a hidden economy. The benefits of formalization include enforceable commercial contracts, exposure to government patronage, larger market, and access to bank facilities (Chen [1]). However, in literature, a lot of reasons have been ascribed to business entry barriers. These range from costly regulations and long procedures (Loayza et al. [8], Klapper et al. [9], Obamuyi [10]), lack of access to funds, corruption, and unfavourable business environments. Some studies found out that reducing the registration cost and removing entry barriers could reduce informality.

The formalisation debate usually focuses on informal wage workers and the selfemployed. In this study, attention will be focused on the self-employed. In the formal sector in Nigeria, a business should register with different government agencies (e.g. the Corporate Affairs Commission (CAC) and Revenue Agencies). Those with more than 10 employees are required to register with the Pension Fund and National Housing Fund.

\section{METHODOLOGY}

\subsection{Sample}

A total of 200 micro-entrepreneurs were administered with a questionnaire, but only 161 responded, representing an 80.5 per cent response rate. Business owners were purposely selected from five major informal business towns, namely, Ojuore, Atan, Obere, Lusada and Iyana in the Ota area, Ogun State, Nigeria. This area has the highest concentration of microbusinesses in Ogun State, Nigeria.

\subsection{Variable description and data analysis}

Five lines of business were chosen for the survey. These include light manufacturing, trading, agro-allied, and vocation and professional services. The business focus was chosen as a good representation of the self-employed and microbusiness owners and a true reflection of various sectors in the informal economy. The questionnaire is designed to collect information on a 
firms' performance and characteristics, and measure formality in terms of registration and licensing.

In this study, we focus on income as a dependent variable due to the fact that the impact on income is a key determinant when a firm decides on whether or not to register. We also consider independent variables such as the owner's education level, business age, business focus, business type, sex, business registration and license. These are expected to affect business performance and income. In the choice of performance measures, Stranger [11] recommends that the ease of analysis of parameters must be considered - this is what we have done in this study. Probit regression was used to develop the predictive model for whether income improves or not. A probit model is simple to analyse and can produce results that can be easily interpreted. The probit model for this study is specified as follows:

$$
y=\alpha_{0}+\alpha_{1} x_{1}+\alpha_{2} x_{2}+\alpha_{3} x_{3}+\alpha_{4} x_{4}+\alpha_{5} x_{5}+\alpha_{6} x_{6}+\alpha_{7} x_{7}+\alpha_{8} x_{8}+e_{1}
$$

In a more compact form, the equation can be re-written as:

$$
y_{i}=\sum_{i}^{n} \alpha_{i} x_{i}+e_{i} \ldots
$$

where:

$y_{i}=$ If the probability of increasing income is high, 1 and otherwise, 0 .

$x_{1}=$ Sex; 1 for male and 0 for female $x_{2}$.

$x_{2}=$ Age of owner; 1 for 20-65 years, and 0 for otherwise.

$x_{3}=$ Business focus; 1 for trading and 0 for otherwise.

$x_{4}=$ Business type of ownership, 1 for sole proprietorship, 0 for otherwise.

$x_{5}=$ Years started; 1 for above 5 years and 0 for otherwise.

$x_{6}=$ Education level; 1 for post-secondary and 0 for otherwise.

$x_{7}=$ Business registration; 1 for registered and 0 for otherwise.

$x_{8}=$ Business product license; 1 for licensed, 0 for otherwise.

$\alpha_{0}=$ Constant (A).

$\alpha_{i}=$ Regression coefficients.

$e_{i}=$ Error term.

\section{ANALYSIS OF SOCIO-ECONOMIC CHARACTERISTICS OF RESPONDENTS}

\subsection{Gender}

The gender structure, as shown in Table 1, indicates a bias towards male dominance, which accounts for $110(68.3 \%)$ of the sampled business owners, while female accounts for 51 $(31.7 \%)$. The lower percentage of women business owners is due to sociological reasons, as women are expected to take care of matters related to the home. The majority of females who are involved in business are traders and their businesses are located very close to their homes.

\subsection{Age of business owners}

The age structure of the enterprise owners was classified into four groups, as shown in Table 1 . It showed that only $13(8.1 \%)$ of the respondents are above 60 years and about 16.8 per cent are less than 30 years old. Some 46 per cent were between the ages of 30 and 39 years, while 29.2 per cent were between 40 and 49 years old. This shows that 91.9 per cent of the microenterprises owners are in the active age bracket (30-59 years). The age structure also shows that most of the respondents are mature and of working age, with a high degree of survival instinct. 


\subsection{Business focus}

There are five distinct business lines predominant in the Ota area. These are trading, light manufacturing, agro-allied, and vocational and professional services. It is important to know that vocational (34.8\%) and trading (34.2\%) are the most predominant lines of businesses. This is followed by light manufacturing at 16.8 per cent (such as metal works/engineering products), and professional service providers at 8.7 per cent. The least is agro-allied (5.6\%), such as palm-oil mills, cassava flour and chip processing. Most find trading very profitable with less risk. The lack of entry barriers and flexibility also makes trading and vocation very attractive to microbusiness owners. Bakeries, block making, soap making, shoe making, tailoring, furniture and food processing are becoming popular in this area.

\subsection{Business type/ownership structure}

The distribution of respondents by business type shows that the majority (79.5\%) are of sole proprietorship. 17.4 per cent of the businesses are limited liability companies, while only 3.1 per cent are in partnership. This shows that many people are not well disposed to the idea of having a joint business, possibly due to the idea of self-recognition or self-esteem.

\subsection{Years of operation/age of business}

Some of the businesses $(33.5 \%)$ were established within the last five years, as shown in Table 1. Those established within the last 10 years comprise 34.8 per cent of the total number of the respondents, while 31.7 per cent had been in operation for more than 10 years. This shows that a sizeable number of the businesses (66.5\%) are older than five years; indicating that the survival rate of microenterprises in Ota area is high. The implication is that three out of every five in the area will survive more than five years, and three out of every 10 survive above 10 years.

\subsection{Level of education}

The majority of the microenterprises owners $(83 ; 51.6 \%)$ attended secondary schools. Some $55(34.2 \%)$ respondents attended tertiary institutions, while $17(10.6 \%)$ attended only primary schools. Six $(3.7 \%)$ of the respondents have no formal education at all. The implication of this is that most microenterprise owners in the study area are formally literate. However, most of them still lack good managerial and financial education, which is necessary for business growth and sustainability.

\subsection{Business registration}

It is common among the microenterprises to remain unregistered for a long period of time. This makes it difficult for them to obtain financial assistance from banks. Table 1 shows that of the 161 microenterprises surveyed, 31 were registered with a government agency (CAC) while 89 were registered with local trade associations, and 41 were not registered at all. This indicates a high level of misconception about the importance of business registration.

\subsection{Business license}

A total of $56(35 \%)$ out of 161 businesses surveyed had their businesses and products licensed, while 105 (65\%) did not have their businesses licensed, as shown in Table 1. This indicates their inaccurate perceptions about the significance of having a business license. 
Table 1: Socio-economic profile of selected microenterprises in Ota area. (Source: Field work, 2015.)

\begin{tabular}{|c|c|c|c|}
\hline & & Frequency & Percentage \\
\hline \multirow[t]{2}{*}{ Sex } & Male & 110 & $68.3 \%$ \\
\hline & Female & 51 & $31.7 \%$ \\
\hline \multirow[t]{4}{*}{ Age } & Below 30 years & 27 & $16.8 \%$ \\
\hline & $30-39$ years & 74 & $46.0 \%$ \\
\hline & $40-49$ years & 47 & $29.2 \%$ \\
\hline & 60 years and above & 13 & $8.1 \%$ \\
\hline \multirow[t]{5}{*}{ Business focus } & Trading & 55 & $34.2 \%$ \\
\hline & Light manufacturing & 27 & $16.8 \%$ \\
\hline & Vocational & 56 & $34.8 \%$ \\
\hline & Agro-allied & 9 & $5.6 \%$ \\
\hline & Professional & 14 & $8.7 \%$ \\
\hline \multirow[t]{3}{*}{ Business type } & Sole entrepreneur & 128 & $79.5 \%$ \\
\hline & Partnership & 5 & $3.1 \%$ \\
\hline & Limited liability company & 28 & $17.4 \%$ \\
\hline \multirow[t]{3}{*}{ Year started } & $1-5$ years & 54 & $33.5 \%$ \\
\hline & $6-10$ years & 56 & $34.8 \%$ \\
\hline & Above 10 years & 51 & $31.7 \%$ \\
\hline \multirow[t]{4}{*}{ Educational level } & No formal schooling & 6 & $53.89 \%$ \\
\hline & Primary & 17 & $3.7 \%$ \\
\hline & Secondary & 83 & $10.6 \%$ \\
\hline & Tertiary & 55 & $34.2 \%$ \\
\hline \multirow{2}{*}{$\begin{array}{l}\text { business registration } \\
\text { location }\end{array}$} & Otherwise & 41 & $25 \%$ \\
\hline & Registered & 120 & $74 \%$ \\
\hline \multirow[t]{2}{*}{ Business production license } & Otherwise & 105 & $65.15 \%$ \\
\hline & Yes & 56 & $34.85 \%$ \\
\hline
\end{tabular}

\section{REGRESSION ANALYSIS OF FACTORS INFLUENCING MICROENTERPRISE OUTCOMES}

The age of the business has a positive and insignificant effect on the income generation of microenterprises, as shown in Table 2. This is in line with a priori expectation. The implication is that the older the age of the business, the greater the possibility of making more income. This might be due to the loyalty of existing customers and the goodwill of the business.

The results also show that the coefficient of business type is positive but insignificant. This suggests that one-man businesses have a tendency to generate more income; this is counter-intuitive. The general belief is that the more owners of a business there are, the more opportunity for business expansion and growth. But in this study area, the issue of selfrecognition and quick decision-making could play a key role in boosting the business income of one-man businesses.

The coefficient of business focus is significant but negative. Owing to a less risky nature of trading activities, a sizable number of businesses involve trading, and in most cases little 
income is generated. This is in conformity with the fact that the more the risk, the more the returns.

The age of owners has a positive but not significant effect on income. The majority of the business owners are in the working age bracket. This also shows that the more mature they are, the more experienced they become.

Gender has a negative and significant effect on income. This implies that, contrary to the belief that men are more energetic and are the bread winners, most women in microbusiness are more business-minded and shrewd in the Ota area, hence the positive effect on business.

The level of education has a positive but insignificant effect on income. This suggests that the level of education of micro-entrepreneurs has little part to play in income-generation capacity. Most transactions are conducted at grass roots and local levels.

The results of business registration and licensing are counter intuitive. The coefficients on business registration and business licensing are negative and insignificant. This suggests that the registration and licensing of a microenterprise business were perceived as factors that may hinder the ability of the business to generate income. Ordinarily, business formality (registration and licensing) should serve as an incentive rather than disincentive to business growth. One major reason for this counter-intuitive result might be significantly due to a lack of adequate information about the importance of business registration. It might also be as a result of administrative bottlenecks in business registration and licensing in Nigeria, as revealed in the study. In many instances, the process of registration is cumbersome and relatively expensive. Since those who do not register operate and get away with it, then many businesses would be discouraged to register and will perceive registration as a hindrance to their business survival. However, most of the microenterprises preferred to register with their local associations.

\section{CONCLUSIONS}

The results showed that gender and business focus were significant factors determining the income-generation potential of microenterprises. However, business type, business registration, licensing, age of business, educational level, and age of owners, were not significant in determining the income generation of the firms. Furthermore, the result showed that business formality (registration and licensing) does not have any significant effect on the firms' outcome among the microenterprises. The study concluded that business formality is not an important factor, and has no significant effect on the income generation potential of microenterprises in the Ota area, Nigeria.

Table 2: Summary of results for the probit regression.

\begin{tabular}{lllllll}
\hline & Coef. & Std. Err. & Z-stat & P > | z | & 95\% conf. & Interval \\
\hline Sex & -0.3945555 & 0.1562617 & -2.52 & 0.012 & -0.7008229 & -0.0882881 \\
\hline Age & 0.168994 & 0.1527007 & 1.10 & 0.269 & -0.1305939 & 0.4679819 \\
\hline Bizfocus & -0.2968162 & 0.1544101 & -1.92 & 0.055 & -0.5994546 & 0.0058221 \\
\hline BizType & 0.0163185 & 0.2058559 & 0.08 & 0.937 & -0.3871518 & 0.4197887 \\
\hline Yearstarted & 0.0030822 & 0.1573781 & 0.02 & 0.984 & -0.3053733 & 0.3115377 \\
\hline Educ Level & 0.0492428 & 0.1436615 & 0.34 & 0.732 & -0.2323286 & 0.3308143 \\
\hline B1BizRegLoation & -0.0659989 & 0.1720042 & -0.38 & 0.701 & -0.403121 & 0.2308143 \\
\hline B1BizProdLicence & -0.0401246 & 0.1604606 & -0.25 & 0.803 & -0.3546216 & 0.2743724 \\
\hline con & -0.03444947 & 0.3447428 & -1.10 & 0.920 & -0.7101782 & 0.6411888 \\
\hline
\end{tabular}

LR chi $(8)=8.82$.

Prob $>$ chi $=0.3577$.

Pseudo $\mathrm{R}^{2}=0.0186$. 


\subsection{Recommendations}

In spite of the advantages of business registration and licensing, this study has revealed that the majority of the micro-entrepreneurs in this study area are not interested in formality due to the costs and cumbersome processes of registration. Many preferred to register with local trade organizations. Therefore, to stir up the interest of these business owners, all the entry barriers to the business formalisation of microenterprises should be critically addressed. Suffice it to say that the processes should be simplified in terms of reduction in the number of days, number of steps, and forms to fill with a view to reducing the costs. Furthermore, it is important that the government promote a robust enlightenment campaign about the advantages of business registration and licensing, especially among the microenterprises. The programmes and projects of government towards industrial and entrepreneurial development should be made more specific and target-oriented.

\section{REFERENCES}

[1] Chen, M.A., The informal economy: Definitions, theories and policies. WIEGO Working Paper No. 1, Aug. 2012.

[2] Fajnzylber, P., Maloney, W.F. \& Montes-Rojas, G.V., Does formality improve microfirm performance? Evidence from the Brazilian SIMPLES program. Journal of Development Economics, 94, pp. 262-276, 2011.

[3] Bruhn, M. \& Mckenzie, D., Entry regulation and formalization of microenterprises in developing countries. World Bank Policy Research Working Paper No. 6507, 2013.

[4] De Soto, H., The Other Path: The Invisible Revolution in the Third World, Harper and Row: New York, 1989.

[5] Paul, R. \& Wallace, C., Household work strategies in economic recession. Beyond Employment. Household, Gender and Subsistence, eds N. Redcliff \& E. Mingion, Blackwell: Oxford, pp. 189-227, 1985.

[6] Portes, A. \& Sassen-Koob, Making it underground: Comparative material on the informal sector in Western market economies. American Journal of Sociology, 93(1), pp. 30-61, 1987.

[7] Ferman, H. \& Hoyman, M., Issues and prospects for the study of informal economies, concepts, research strategies and policy. The Annals of the American Academy of Political Science, 493, pp. 154-172, 1987.

[8] Loayza, N., Oviado, A.M. \& Serven, L., The impact of regulation on growth and informality: Cross country evidence. World Bank Policy Research, Working Paper No. 3623, World Bank: Washington, DC, 2005.

[9] Klapper, L., Laeven, L. \& Rajan, R., Entry regulation as a barrier to entrepreneurship. Journal of Financial Economics, 82(3), pp. 591-629, 2006.

[10] Obamuyi, T.M., Determinants of factors influencing the profitability of small and medium business in Ondo State Nigeria. An econometric approach. Journal of Economics and Financial Studies, 2005, pp. 147-156, 2005.

[11] Stranger, A.M., Home-based business marginality. A review of home-based business performance and its determinants. School of Commence Research Paper, Series 17, 2000. 